九州大学学術情報リポジトリ

Kyushu University Institutional Repository

Human Nanog pseudogene8 promotes the proliferation of gastrointestinal cancer cells 内野，慶太

https://doi.org/10.15017/1441343

出版情報 : 九州大学，2013，博士（医学），論文博士 バージョン：

権利関係：やむを得ない事由により本文ファイル非公開（2） 


\section{Human Nanog pseudogene8 promotes the proliferation of gastrointestinal cancer cells}

Keita Uchino ${ }^{1}$, Gen Hirano ${ }^{1}$, Minako Hirahashi ${ }^{2}$, Taichi Isobe $^{1}$, Tsuyoshi Shirakawa ${ }^{1}$, Hitoshi Kusaba ${ }^{1}$, Eishi Baba ${ }^{1}$, Masazumi Tsuneyoshi ${ }^{2}$, and Koichi Akashi ${ }^{1}$

${ }^{1}$ Department of Medicine and Biosystemic Science, Kyushu University Graduate School of Medical Sciences, Fukuoka, Japan

${ }^{2}$ Department of Anatomic Pathology, Graduate School of Medical Sciences, Kyushu University, Fukuoka, Japan.

Corresponding author: Keita Uchino

3-1-1 Maidashi, Higashi-ku, Fukuoka 812-8582, Japan

Tel: +81-92-6425232; Fax: +81-92-6425247

E-mail: uchino13@intmed1.med.kyushu-u.ac.jp 


\begin{abstract}
There is emerging evidence that human solid tumor cells originate from cancer stem cells (CSCs). In cancer cell lines, tumor-initiating CSCs are mainly found in the side population (SP) that has the capacity to extrude dyes such as Hoechst 33342 . We found that Nanog is expressed specifically in SP cells of human gastrointestinal (GI) cancer cells. Nucleotide sequencing revealed that NanogP8 but not Nanog was expressed in GI cancer cells. Transfection of NanogP8 into GI cancer cell lines promoted cell proliferation, while its inhibition by anti-Nanog siRNA suppressed the proliferation. Immunohistochemical staining of primary GI cancer tissues revealed NanogP8 protein to be strongly expressed in 3 out of 60 cases. In these cases, NanogP8 was found especially in an infiltrative part of the tumor, in proliferating cells with Ki67 expression. These data suggest that NanogP8 is involved in GI cancer development in a fraction of patients, in whom it presumably acts by supporting CSC proliferation.
\end{abstract}

Key Words: Nanog, Nanog P8, proliferation, gastrointestinal cancer, cancer stem cells 


\section{Introduction}

Cancer stem cells (CSCs) possess a self-renewal capacity and tumorigenicity, properties that have been demonstrated mainly by serial tumor transplantation into immune-deficient mice [1]. Following the initial identification of leukemic stem cells, CSCs have been discovered in various solid tumors, including breast and brain cancers [2, 3]. Human gastrointestinal (GI) cancers have also been suggested to contain CSCs. Side population (SP) cells are thought to include CSCs with self-renewal capacity and high tumorigenicity [4].

Embryonic stem cells (ESCs) have biological features with pluripotency and robust proliferation. Nanog is one of the key transcription factors important for maintaining pluripotency by regulating ESC differentiation. Nanog is gradually down-regulated in accordance with ESC differentiation, and is not present in differentiated somatic cells $[5,6]$. Overexpression of Nanog enhances self-renewal activity in ESCs [7, 8]. Nanog expression has been reported in several human tumors [9-18] and especially highly detected in CSCs $[12,16,18]$. Considering the analogy between embryogenesis and tumorigenesis, Nanog might have a proliferative function in cancer cells including GI cancers.

Human Nanog is encoded by Nanog and 11 Nanog mRNA variants derived from alternative loci $[19,20]$. Of the variants, NanogP8 contains a complete open reading frame and the protein coding region, and is closely homologous to Nanog. However, functional differences between Nanog and NanogP8, and their gene-expression profiles in cancer cells, have not been clarified.

Here, we describe increased Nanog expression in SP cells of human GI cancer. 
Surprisingly, NanogP8 but not Nanog was preferentially detected in clinically obtained GI cancer cells and its expression was closely related to the proliferative activity of the cancer cells. 


\section{Materials and Methods}

\section{Cell lines and culture}

Human gastric cancer cell lines (AZ521, MKN1) and the murine fibroblast cell line NIH3T3 were purchased from ATCC and cultured in Dulbecco's Modified Eagle's Medium (DMEM) containing 10\% fetal bovine serum (FBS) and streptomycin. Human colon cancer cell lines (SW480, DLD1) and a human breast cancer cell line (MCF7) were provided by the Cell Resource Center of Biomedical Research, Institute of Development, Aging and Cancer (Tohoku University, Sendai, Japan). SW480, DLD1, MCF7, and the human embryonic carcinoma cell line NEC8 were cultured in RPMI-1640 medium containing 10\% FBS. NIH3T3 cells were negative for Nanog; NEC8 and MCF7 cells were positive for Nanog expression.

\section{Cancer cells isolated from ascites and pleural effusion of GI cancer patients}

Ascites and pleural effusion of GI cancer patients were obtained in the Department of Hematology and Oncology, Kyushu University Hospital and Sawara Hospital, Fukuoka, Japan. All patients were diagnosed with cancer by cytological examination of fluids, and samples were obtained from fluid that had been drained to relieve symptoms. All patients were informed and agreed to participate in the study. The study was approved by the local ethical committee in Kyushu University Hospital in March 2009. We tested samples from 18 patients with GI cancer as follows: sample numbers \#8, \#12, \#18 were ascites of colon cancer; samples \#1, \#2, \#4, \#13, \#17 were pleural effusion of gastric cancer; samples \#3, \#5-7, \#9-11, \#14-16 were ascites of gastric cancer. Cells were collected from the sample 
fluids by centrifugation with LSM (MP Biomedicals, Solon, $\mathrm{OH}$ ).

Reverse Transcription Polymerase Chain Reaction (RT-PCR)

Total RNA was extracted from the cells using Isogen (Invitrogen, Carlsbad, CA) with DNaseI (TaKaRa, Ohtsu, Japan) treatment. Complementary DNA (cDNA) was synthesized from $1 \mu \mathrm{g}$ total RNA using SuperScript II reverse transcriptase (Invitrogen) and oligo-dT3' primer in a total volume of $20 \mu \mathrm{l}$. cDNA $(1 \mu \mathrm{l})$ was amplified by PCR using High Fidelity PCR Master (Roche, Mannheim, Germany). The primers used were as follows: Nanog (930 bp), forward, 5'-AAACGCGGATCCATGAGTGTGGATCCAGCTTGTC-3' and reverse, 5'-ACGCGTCGACTCACACGTCTTCAGGTTGCATG-3'; MDR I (484 bp), forward, 5'-CAGAAACAACGCATTGCCATAGCTC-3' and reverse, 5'-TGATGATGTCTCTCACTCTGTTCC-3'; $\beta$-actin (375 bp), forward, 5'-CGTGACATTAAGGAGAAGCTGTGC-3' and reverse, 5'-CTCAGGAGGAGCAATGATCTTGAT-3'. PCR conditions, using a PCR Thermal Cycler (Takara), were as follows: $95^{\circ} \mathrm{C}$ for $5 \mathrm{~min} ; 18$ or 38 cycles at $95^{\circ} \mathrm{C}$ for $60 \mathrm{~s}, 58^{\circ} \mathrm{C}$ for $60 \mathrm{~s}$, and $72^{\circ} \mathrm{C}$ for $60 \mathrm{~s}$; final elongation at $72^{\circ} \mathrm{C}$ for $10 \mathrm{~min}$. The PCR products were separated by electrophoresis in $1 \%$ agarose gel and stained with ethidium bromide. The primers were designed to amplify the Nanog protein coding region in both Nanog and NanogP8.

Hoechst 33342 staining and side population cell detection, and sorting

Cells were pre-warmed for $30 \mathrm{~min}$ and then stained for $60 \mathrm{~min}$ at $37^{\circ} \mathrm{C}$ with $5 \mu \mathrm{g} / \mathrm{ml}$ 
Hoechst 33342 at $1 \times 10^{6}$ cells/ml in RPMI with $2 \%$ FBS. Verapamil $(30 \mu \mathrm{g} / \mathrm{ml})$ was used for exclusion of Hoechst 33342 from the cells. Cells were resuspended at $4 \times 10^{6} / \mathrm{ml}$ with $100 \mu \mathrm{g} / \mathrm{ml}$ viability dye 7-amino-actinomycin D (Invitrogen) to exclude dead cells and sorted on a FACSVantageSE (BD Biosciences, Franklin Lakes, NJ). Hoechst-DNA binding was detected by excitation with a UV laser $(355 \mathrm{~nm}$ at $50 \mathrm{~mW})$, followed by a $610-\mathrm{nm}$ short-pass dichroic mirror and $670 \mathrm{LP}$ and $450 \mathrm{BP} 20$ detection filters for red and blue emission wavelengths, respectively. Freshly isolated cells had their RNA extracted with Isogen; cDNA was synthesized and RT-PCR performed as described previously.

cDNA microarray

Total RNA was extracted using TRIzol reagent (Invitrogen) according to the manufacturer's protocol. First-strand cDNA was synthesized from 250 ng total RNA and amplified using the Low RNA Input Fluorescent Labeling Kit (Agilent Technologies, Santa Clara, CA). The cRNA was labeled with Cyanine 3(Cy3)-CTP during in vitro transcription. A total of $825 \mathrm{ng}$ Cy3-labeled RNA was hybridized to the Agilent whole human genome 4 $\times 44 \mathrm{~K}$ commercial oligo-DNA microarray (Agilent Technologies) at $60^{\circ} \mathrm{C}$ for $17 \mathrm{~h}$ and then washed according to the Agilent standard hybridization protocol. Fluorescence intensities on scanned images were quantified, corrected for background noise and normalized using GeneSpring GX software (Agilent Technologies).

Western blot analysis

Nuclear protein was extracted from the 70-90\% confluent cells using NE-PER (Pierce, 
Rockford, IL) with protease inhibitor cocktail I (Calbiochem, Darmstadt, Germany), following the manufacturer's instructions. The protein concentration of the supernatants was determined by BCA Protein Assay (Pierce) and then $40 \mu \mathrm{g}$ protein was applied to SDS-polyacrylamide gels. Proteins were transferred onto polyvinylidene fluoride membranes (Amersham-GE Healthcare), then detected with specific antibodies: polyclonal rabbit anti-human Nanog (1:1000, ReproCELL, Tokyo, Japan), and mouse anti-human nucleoporin (1:2000, BD Pharmingen, San Diego, CA). Membranes were then probed with horseradish-peroxidase-conjugated secondary antibodies and visualized chemiluminescently with an ECL kit (Amersham-GE Healthcare).

\section{Immunohistochemical staining}

All GI cancer specimens were histologically diagnosed and registered at the Department of Anatomic Pathology, Graduate School of Medical Sciences, Kyushu University. The cancers examined were gastric (30 cases) and colon (30 cases). Most of these cancers invaded through the muscularis propria. The resected specimens were fixed in $10 \%$ buffer formalin and embedded in paraffin. These sections were cut to $3 \mu \mathrm{m}$ width, deparaffinized in xylene and dehydrated in alcohol. Microwave pretreatment was performed for 20 min, and endogenous peroxidase activity was blocked by incubation with $3 \%$ hydrogen peroxide in methanol for $20 \mathrm{~min}$. The sections were washed with PBS then incubated with a 1:50 dilution of polyclonal rabbit anti-human Nanog (Reprocell) at $4^{\circ} \mathrm{C}$ overnight. After washing with PBS, the sections were incubated with secondary antibodies (Nichirei, Tokyo, Japan) for $20 \mathrm{~min}$ at room temperature. The slides were then incubated in $0.05 \% \mathrm{Tris}-\mathrm{HCl}$ 
buffer containing 3-3'-diaminobenzidine tetrahydrochloride and $0.01 \% \mathrm{H}_{2} \mathrm{O}_{2}$ for 2 min. Finally, the nuclei were lightly counterstained with Meyer hematoxylin, and the sections were dehydrated and mounted in a routine fashion. These specimens were histologically evaluated by a certified pathologist $(\mathrm{MH})$.

cDNA sequence analysis

The RT-PCR products for the Nanog protein coding region, using a primer pair, were extracted from agarose gel using a gel extraction kit (Qiagen, Valencia, CA) and inserted into the pCR2.1-TOPO vector (Invitrogen). Sequencing analysis was carried out using the Applied Biosystems 3130xl DNAsequencer (Applied Biosystems, Foster City, CA).

\section{Plasmids and transfections}

RT-PCR products encoding the human NanogP8 protein coding region in AZ521 cells were introduced into pT7Blue-2 vector (Novagen, Madison, WI), digested by EcoR I and Not I and subcloned into expression vector pcDNA3. The sequences of human NanogP8 inserted to the pcDNA3 vector were confirmed by cDNA sequencing analysis. AZ521 and SW480 cells were transfected with NanogP8 and empty vector in a 6-well plate using Lipofectamine 2000 reagent (Invitrogen) following the manufacturer's instructions. After $48 \mathrm{~h}$ of transfection, cells were trypsinized, seeded in 10-cm dishes and selected in a medium containing $0.8-1.0 \mathrm{mg} / \mathrm{ml} \mathrm{G} 418$ for 2-3 weeks. Single colonies were chosen, and NanogP8-expressing clones were confirmed by western blot analysis.

NanogP8-overexpressing AZ521 cells were designated AZ521/NanogP8, and empty 
vector-transfected AZ521 cells AZ521/mock. SW480/NanogP8 and SW480/mock cells were produced in the same way.

\section{Immunocytochemical staining}

The cells were cultured on chamber slides (BD Bioscience), and washed in PBS then fixed by cold methanol at $-20^{\circ} \mathrm{C}$ for 10 min and washed with PBS containing $0.1 \%$ Tween20 (0.1\% PBST). After blocking with $0.1 \%$ PBST with $5 \%$ skim milk for $1 \mathrm{~h}$, fixed cells were incubated with anti-Nanog antibodies $\left(1: 50,4^{\circ} \mathrm{C}\right.$ overnight $)$. They were washed with $0.1 \%$ PBST, and treated with Texas-red-conjugated goat anti-rabbit IgG (Molecular Probes) at room temperature for $1 \mathrm{~h}$. After washing in PBS, the cells were coverslipped with a mounting medium containing 4',6-diamidino-2-phenylindole (DAPI, Vector Laboratories, Burlingame, CA).

\section{Proliferation assay}

Cell proliferation was measured by the WST-1 assay (Wako Chemicals, Osaka, Japan). The mock and NanogP8 transfectant cells were seeded on a 96-well microplate $\left(1 \times 10^{4}\right.$ cells/100 $\mu$ l per well). WST-1 solution was added to each well at particular time points, and the plates incubated at $37^{\circ} \mathrm{C}$ for another hour. Absorbance values were measured at $450 \mathrm{~nm}$ and $690 \mathrm{~nm}$ using an Immuno-Mini NJ-2300 plate reader (Bio-Tec, Tokyo, Japan). Each experiment was performed using four replicate wells and carried out independently at least three times. 
Cell cycle assay

The mock and NanogP8 transfectant cells were seeded on a 6 -well microplate $\left(5 \times 10^{4}\right.$ cells $/ \mathrm{ml} \times 2 \mathrm{ml}$ per well). Assay was carried out using the BrdU Flow Kit (BD pharmingen) following the manufacturer's instructions. Analysis was carried out using the FACSAria II(BD Biosciences, Franklin Lakes, NJ).

\section{RNA interference for Nanog gene}

The following double-stranded RNA 25 base pair oligonucleotides for Nanog were generated from Stealth Select RNAi (Invitrogen): for siNanog, 5'-UGAGGCAGGAGAAUGGCGUGAACCC-3'; and for control siRNA, Silencer® Negative Control \#1 siRNA (Ambion, Austin, TX). AZ521 cells $\left(1.0 \times 10^{3}\right.$ cells/well) were seeded in a 96-well plate. The following day, the cells were transfected with the indicated amounts of siRNA. siRNA transfection was performed with Lipofectamine 2000 according to the manufacturer's instructions (Invitrogen). After $48 \mathrm{~h}$, the surviving cells were stained with TetraColor ONE (Seikagaku Corporation, Tokyo, Japan) for $2 \mathrm{~h}$ at $37^{\circ} \mathrm{C}$, according to the manufacturer's instructions.

\section{Immunodeficient mouse xenograft model}

AZ521/NanogP8 cells and AZ521/mock cells were resuspended in DMEM medium then injected subcutaneously $\left(1 \times 10^{7}\right.$ cells/mouse) into 6 10-week-old male RAG2 $\gamma \mathrm{C}(\mathrm{DKO})$ mice, which lack T and B lymphocyte function and NK cells. The two cell types were both injected into the chest lesion of each mouse: AZ521/NanogP8 cells to the right side, and 
AZ521/mock cells to the left. The maximum tumor dimension was measured daily after injection. 


\section{Results}

\section{Expression of Nanog in side population cells}

The SP cells of GI cancer, which show a lower fluorescence intensity on flow cytometry, were thought to possess self-renewal capacity and high tumorigenicity. SP cells were detected at a level of $0.5 \%$ of total SW480 cells: this population disappeared in the presence of verapamil (Fig. 1A).

To investigate the gene-expression profile of SP cells in SW480 cells, RNAs isolated from sorted SP and non-SP cells were examined by cDNA microarray analysis. Our selected criteria is below; 1) genes which had been highly expressed more than double in SP cells by cDNA microarray, 2) genes which had been confirmed by RT-PCR.

Octamer and Sox has been detected in several human cancers, indicating a potential function in carcinogenesis. In ESCs, Nanog is made regulated by a pair of adjacent Octamer and Sox elements, and is not present in differentiated somatic cells. So we selected Nanog (Fig. 1C). SP cells expressed the following genes more strongly than non-SP cells: $\mathrm{ABC}$ transporter genes (ABCG2, MDR1), ES cell transcription factors (Nanog, POU5F1, Sox2, ZIC3, HESX1, STAT3, LEFTY2), several genes that encode developmentally related homeodomain proteins (LBX1, HOXB1, HOP, LHX5, DLX5, TITF1), and several Wnt and Notch signal-related genes; cell-cycle-related genes were decreased in SP cells (Fig. 1B). We hypothesized that Nanog is functionally expressed in human GI cancer cells.

\section{Expression of Nanog in human GI cancer cell lines}

To study the expression of Nanog in human GI cancer cells, its mRNA expression level 
was examined in two gastric cancer cell lines (AZ521, MKN1) and two colon cancer cell lines (SW480, DLD1) by RT-PCR analysis. Nanog mRNA has been reported previously to be detected in AZ521 cells and SW480 cells as well as in NEC8 embryonic carcinoma cells and MCF7 breast cancer cells but not in NIH3T3 fibroblast cells [5, 6, 10, 11, 14, 21] (Fig. 2A). AZ521 cells and SW480 cells also expressed a low level of Nanog protein in the nucleus (Fig. 2B). Using immunocytochemical (ICC) staining, we confirmed that Nanog protein was expressed in the nucleus of a small percentage (less than $1 \%$ ) of these cells (data not shown).

\section{Expression of Nanog in human GI cancer tissues}

To examine the expression of Nanog mRNA in human GI cancer cells, RT-PCR analyses were performed in cancer cells obtained from ascites and pleural effusions of patients with GI cancer. Nanog mRNA was expressed in 12 out of 18 patients (Fig. 2C). Cancer cells obtained from ascites of a patient with poorly differentiated gastric adenocarcinoma expressed a high level of Nanog protein (Fig. 2D). To exclude the possibility that Nanog was expressed in normal inflammatory cells contaminating the ascites, the expression of Nanog was examined in peripheral blood mononuclear cells (PBMC). No Nanog was detected in PBMC using RT-PCR or western blot (Figs. 2C and 2D).

NanogP8 is expressed in GI cancer cells

Four nucleotides are different in the cDNA of human NanogP8 and that of Nanog, based on sequences in the GenBank (accession number NM_024865.2 and BC099704.1, 
respectively). These differences in base sequence cause two changes in amino acids: Lys82 to Asn82 and Gln253 to His253. To identify the sequences of Nanog expressed in clinical samples, the PCR products, amplified with a primer pair for human Nanog cDNA, were subcloned, and 22 transformants were sequenced. The sequences of 19 of these clones were identical to those of human NanogP8; 3 clones had sequences with no homolog in the GenBank database (Fig. 3A and 3B). No clone was identical to human Nanog or Nanog splicing variant forms [22]. These results suggest that GI cancer tissues preferentially express NanogP8.

NanogP8 promotes cell proliferation in NanogP8-transfected cancer cells

To investigate the function of NanogP8, we first tried to establish NanogP8-overexpressing AZ521 clones by limiting dilution. Although a small percentage of AZ521 single clones clearly expressed NanogP8, it was difficult to maintain their expression level in a culture system. Instead, human NanogP8 cDNA was introduced into AZ521 cells and SW480 cells, and four stable transfectants that overexpressed NanogP8 were established (AZ521/NanogP8 \#1, AZ521/NanogP8 \#2, SW480/NanogP8 \#1 and SW480/NanogP8 \#2; Fig. 4A). Nanog proteins of 35-50 kDa were detected by western blotting as reported previously $(14,25)$. ICC staining also showed NanogP8 to be expressed in the nucleus of these transfectants (Fig. 4B).

AZ521/NanogP8 \#1 and AZ521/NanogP8 \#2 cells proliferated more than AZ521/mock cells (Fig. 5Aa). The mean doubling times of AZ521/mock clones and AZ521/NanogP8 clones were $45.1 \pm 4.1 \mathrm{~h}$ and $28.4 \pm 3.2 \mathrm{~h}$, respectively. SW480/NanogP8 \#1 also 
proliferated more than SW480/mock cells (Fig. 5Ab). The mean doubling times of SW480/mock clone and SW480/NanogP8 clone were $20.8 \pm 6.9 \mathrm{~h}$ and $6.71 \pm 2.1 \mathrm{~h}$, respectively. The knockdown of endogenous NanogP8 by siRNA in parental AZ521 cells decreased the absorbance ratio comparative to control cells (without siRNA treatment) in a concentration-dependent manner (Fig. 5C).

We investigated the mechanism of proliferation promoted by NanogP8, and identified that the percentage of S phase in NanogP8 transfectants was higher in comparison with the mock control in cell cycle assay using BrdU (Fig. 5B). This result indicate that expression of exogenous NanogP8 gene promotes cells to enter into S phase of the cell cycle, and promotes the proliferation of gastrointestinal cancer cells.

We next explored in vivo tumorigenicity and proliferation of NanogP8 transfectants. AZ521/NanogP8 cells and AZ521/mock cells were injected into immunodeficient mice to evaluate the formation of tumors. The tumors from four AZ521/NanogP8 clones were larger than the tumors from four AZ521/mock clones (Fig. 6). These results suggest that NanogP8 promotes tumor formation of the GI cancer cells.

\section{The expression of NanogP8 in the primary site of human GI cancers}

We examined the expression of NanogP8 in the primary site of human GI cancers by immunohistochemical (IHC) staining. NanogP8 was expressed in 3 of 60 samples: 2 gastric cancers and 1 colon cancer. In these samples, the differentiated cells consisted mostly of tumor tissues, which were highly desmoplastic and showed high nuclear atypia and many mitoses of tumor cells. The first sample (Fig. 7A, B, C) was moderately to poorly 
differentiated gastric adenocarcinoma, stage IIIB (T3N2M0). This sample showed cancer cells in infiltrative part-formed small or crumbled glands (sprouting forms); stromal tissues around the tumor cells were highly fibrously thickened (desmoplastic reaction). NanogP8-expressing cells were present at $10 \%$ in the neighborhood of desmoplasia in the infiltrative part, but not in the surface part (Fig. 7B, C). The second sample (Fig. 7D, E) was well-differentiated gastric adenocarcinoma, stage IV (T2N3M0). This sample showed NanogP8-expressing cells at 5\% overall, but more strongly in the infiltrative parts (Fig. 7E). The third sample (Fig. 7F, G) was from a patient with moderately differentiated colon adenocarcinoma, stage IIIB (T3N1M0). The infiltrative part of this sample showed irregularly structured cancer cells. NanogP8 was heterogeneously expressed at $8 \%$ in the enlarged nuclei (Fig. 7G). In all samples, NanogP8 was expressed in the nuclei of the cancer cells. Ki67 staining, which is related to cell proliferation, was stronger in tumor-infiltrating parts of these samples (Fig. $7 \mathrm{H})$. Examination of these samples indicated that NanogP8 was strongly and heterogeneously expressed in the infiltrating part of the cancers, where the proliferation activity is high. 


\section{Discussion}

Previous study was reported that SW480 cells had contained SP cells, which had possessed higher tumorgenic potential than non-SP cells [23]. Therefore, in this study, we presupposed that SP cells had contained a high proportion of CSCs and we selected SP cells to enrich CSCs. Subsequently, we exhaustively analysed them to detect specifically high-expressed genes in those population by cDNA microarray assay. There have been several reports that overexpression of ESC-related molecules in human cancer cells enhances cell proliferation and correlates with poor prognosis [24, 25]. For example, Nanog was highly expressed in CD44 $4^{\text {high }} \mathrm{CSC}$ s of human prostate cancer, and was suggested to promote cancer development by enhancing self-renewal in cancer cells [26]. We have revealed that NanogP8 is strongly expressed in CSCs of GI cancer. Additionally, human GI cancer samples revealed strong expression of NanogP8 in the nuclei of a small percentage of cancer cells at the infiltrating part of the cancer, i.e., the actively proliferating part where Ki67 expression was high. These results suggest that human NanogP8 predominantly promotes proliferation in CSCs of GI cancer.

We investigated the mechanism of proliferation promoted by NanogP8, and identified the activity of cell cycles. SP cells are population in which CSCs are supposed to be enriched, but non-CSCs are also included. We think that decreased expression of cell cycle genes in the SP cells has not been reflected in cell cycle activity of Nanog-expressing cells. Since transfection of NanogP8 was shown to promote cell cycle activity in the analysis with BrdU, we think NanogP8-expressing cells may be a population with efficient proliferative activity, which consists of selfrenewal potential of CSCs. 
The limitation of our study, the co-staining with NanogP8 and Ki67 in human tissue could not been shown, therefore, it was been uncleary that the same cells had expressed both NanogP8 and Ki67. In the result of cell cycle assay of NanogP8 transfected cells, we assumed the possibility that NanogP8-expressing tumor cells had concurrently expressed Ki67 in most if not all cases. But we could not deny the possibility that NanogP8-expressing tumor cells would promote proliferation in surrounding cells.

Of 11 human Nanog pseudogenes, only NanogP8 has a complete open reading frame, which is closely homologous to Nanog apart from two amino acid alterations, K82N and Q253H. The DNA-binding activity of Nanog has been shown to relate to the amino acid residues from K95 to Q154. As the altered amino acid residues are found in the C-terminus of NanogP8 rather than the active region, NanogP8 is expected to be able to interact with DNA. In our study, NanogP8 was expressed in the nuclei of cancer cells, and its overexpression promoted proliferation of GI cancer cell lines. These findings suggest that NanogP8 functions as a transcriptional factor and is involved in cell proliferation.

Transcriptional regulation of Nanog in ESCs has been well studied: a pair of adjacent Octamer and Sox elements exists between positions $-118 \mathrm{bp}$ and $-104 \mathrm{bp}$ from the translational starting site [27]. In contrast, the region from -1000 bp to the translational starting site of NanogP8 does not possess the adjacent Octamer and Sox elements. Therefore, we suggest that NanogP8 is regulated differently from Nanog. Human Nanog and NanogP8 genes are located on chromosomes 12p13.31 and 15q13.3, respectively. The molecular mechanisms of selective expression of Nanog and NanogP8 remain unclear. One possible explanation is that only the Nanog locus might be 
silenced in cancer cells: the Nanog locus in differentiating ESCs is silenced by histone acetylation [26].

In conclusion, NanogP8 is involved in GI cancer development in a fraction of patients, in whom it presumably acts by supporting CSC proliferation. The frequency of GI cancer patients with increased expression of NanogP8 was low in our study, so the clinical significance of NanogP8 expression is still unclear. A larger-scale study employing clinical samples from patients with different clinical courses would solve this problem. In order to understand the functional roles of NanogP8 in CSCs of GI cancer, CSCs selectively isolated by adequate molecular markers should be utilized. Clarification of NanogP8 function in maintenance and proliferative phases of CSCs might provide a novel therapeutic strategy for GI cancers by targeting NanogP8. 


\section{Acknowledgments}

The authors would like to thank Dr Fumihiko Ishikawa and colleagues for technical support for flow cytometry, Dr Risa Tanaka, and Dr Tanji Tsuchiya for providing clinical samples, Dr Shuichi Kurihara and Dr Masaki Gushima for technical support for immunohistochemical staining, and Dr Ryo Matoba for technical support for cDNA microarray. The authors also would like to acknowledge the technical expertise of the Support Center for Education and Research, Kyushu University. This work was supported by a Health and Labor Sciences Research Grant from the Ministry of Health, Labor and Welfare of Japan. 


\section{Reference}

[1] D. Bonnet, J.E. Dick, Human acute myeloid leukemia is organized as a hierarchy that originates from a primitive hematopoietic cell, Nat Med 3 (1997) 730-737.

[2] M. Al-Hajj, M.S. Wicha, A. Benito-Hernandez, S.J. Morrison, M.F. Clarke, Prospective identification of tumorigenic breast cancer cells, Proc Natl Acad Sci U S A 100 (2003) 3983-3988.

[3] S.K. Singh, C. Hawkins, I.D. Clarke, J.A. Squire, J. Bayani, T. Hide, R.M. Henkelman, M.D. Cusimano, P.B. Dirks, Identification of human brain tumour initiating cells, Nature 432 (2004) 396-401.

[4] N. Haraguchi, T. Utsunomiya, H. Inoue, F. Tanaka, K. Mimori, G.F. Barnard, M. Mori, Characterization of a side population of cancer cells from human gastrointestinal system, Stem Cells 24 (2006) 506-513.

[5] I. Chambers, D. Colby, M. Robertson, J. Nichols, S. Lee, S. Tweedie, A. Smith, Functional expression cloning of Nanog, a pluripotency sustaining factor in embryonic stem cells, Cell 113 (2003) 643-655.

[6] K. Mitsui, Y. Tokuzawa, H. Itoh, K. Segawa, M. Murakami, K. Takahashi, M. Maruyama, M. Maeda, S. Yamanaka, The homeoprotein Nanog is required for maintenance of pluripotency in mouse epiblast and ES cells, Cell 113 (2003) 631-642. 
[7] H. Darr, Y. Mayshar, N. Benvenisty, Overexpression of NANOG in human ES cells enables feeder-free growth while inducing primitive ectoderm features, Development 133 (2006) 1193-1201.

[8] S.Y. Yasuda, N. Tsuneyoshi, T. Sumi, K. Hasegawa, T. Tada, N. Nakatsuji, H. Suemori, NANOG maintains self-renewal of primate ES cells in the absence of a feeder layer, Genes Cells 11 (2006) 1115-1123.

[9] A.T. Clark, R.T. Rodriguez, M.S. Bodnar, M.J. Abeyta, M.I. Cedars, P.J. Turek, M.T. Firpo, R.A. Reijo Pera, Human STELLAR, NANOG, and GDF3 genes are expressed in pluripotent cells and map to chromosome 12p13, a hotspot for teratocarcinoma, Stem Cells 22 (2004) 169-179.

[10] U.I. Ezeh, P.J. Turek, R.A. Reijo, A.T. Clark, Human embryonic stem cell genes OCT4, NANOG, STELLAR, and GDF3 are expressed in both seminoma and breast carcinoma, Cancer 104 (2005) 2255-2265.

[11] C.E. Hoei-Hansen, K. Almstrup, J.E. Nielsen, S. Brask Sonne, N. Graem, N.E. Skakkebaek, H. Leffers, E. Rajpert-De Meyts, Stem cell pluripotency factor NANOG is expressed in human fetal gonocytes, testicular carcinoma in situ and germ cell tumours, Histopathology 47 (2005) 48-56.

[12] G. Gu, J. Yuan, M. Wills, S. Kasper, Prostate cancer cells with stem cell characteristics reconstitute the original human tumor in vivo, Cancer Res 67 (2007) 4807-4815. 
[13] C.E. Hoei-Hansen, S.M. Kraggerud, V.M. Abeler, J. Kaern, E. Rajpert-De Meyts, R.A. Lothe, Ovarian dysgerminomas are characterised by frequent KIT mutations and abundant expression of pluripotency markers, Mol Cancer 6 (2007) 12.

[14] S. Santagata, K.L. Ligon, J.L. Hornick, Embryonic stem cell transcription factor signatures in the diagnosis of primary and metastatic germ cell tumors, Am J Surg Pathol 31 (2007) 836-845.

[15] B. Bussolati, S. Bruno, C. Grange, U. Ferrando, G. Camussi, Identification of a tumor-initiating stem cell population in human renal carcinomas, FASEB J 22 (2008) 3696-3705.

[16] S.H. Chiou, C.C. Yu, C.Y. Huang, S.C. Lin, C.J. Liu, T.H. Tsai, S.H. Chou, C.S. Chien, H.H. Ku, J.F. Lo, Positive correlations of Oct-4 and Nanog in oral cancer stem-like cells and high-grade oral squamous cell carcinoma, Clin Cancer Res 14 (2008) 4085-4095.

[17] F. Ye, C. Zhou, Q. Cheng, J. Shen, H. Chen, Stem-cell-abundant proteins Nanog, Nucleostemin and Musashil are highly expressed in malignant cervical epithelial cells, BMC Cancer 8 (2008) 108.

[18] S. Zhang, C. Balch, M.W. Chan, H.C. Lai, D. Matei, J.M. Schilder, P.S. Yan, T.H. Huang, K.P. Nephew, Identification and characterization of ovarian cancer-initiating cells from primary human tumors, Cancer Res 68 (2008) $4311-4320$. 
[19] H.A. Booth, P.W. Holland, Eleven daughters of NANOG, Genomics 84 (2004) 229-238.

[20] I. Eberle, B. Pless, M. Braun, T. Dingermann, R. Marschalek, Transcriptional properties of human NANOG1 and NANOG2 in acute leukemic cells, Nucleic Acids Res 38 5384-5395.

[21] A.H. Hart, L. Hartley, K. Parker, M. Ibrahim, L.H. Looijenga, M. Pauchnik, C.W. Chow, L. Robb, The pluripotency homeobox gene NANOG is expressed in human germ cell tumors, Cancer 104 (2005) 2092-2098.

[22] J.S. Kim, J. Kim, B.S. Kim, H.Y. Chung, Y.Y. Lee, C.S. Park, Y.S. Lee, Y.H. Lee, I.Y. Chung, Identification and functional characterization of an alternative splice variant within the fourth exon of human nanog, Exp Mol Med 37 (2005) 601-607.

[23] S. Inoda, Y. Hirohashi, T. Torigoe, R. Morita, A. Takahashi, H. Asanuma, M. Nakatsugawa, S. Nishizawa, Y. Tamura, T. Tsuruma, T. Terui, T. Kondo, K. Ishitani, T. Hasegawa, K. Hirata, N. Sato, Cytotoxic T lymphocytes efficiently recognize human colon cancer stem-like cells, Am J Pathol 178 1805-1813.

[24] Q. Wang, W. He, C. Lu, Z. Wang, J. Wang, K.E. Giercksky, J.M. Nesland, Z. Suo, Oct3/4 and Sox2 are significantly associated with an unfavorable clinical outcome in human esophageal squamous cell carcinoma, Anticancer Res 29 (2009) 1233-1241. 
[25] M. Schoenhals, A. Kassambara, J. De Vos, D. Hose, J. Moreaux, B. Klein, Embryonic stem cell markers expression in cancers, Biochem Biophys Res Commun 383 (2009) 157-162.

[26] C.R. Jeter, M. Badeaux, G. Choy, D. Chandra, L. Patrawala, C. Liu, T. Calhoun-Davis, H. Zaehres, G.Q. Daley, D.G. Tang, Functional evidence that the self-renewal gene NANOG regulates human tumor development, Stem Cells 27 (2009) 993-1005.

[27] T. Kuroda, M. Tada, H. Kubota, H. Kimura, S.Y. Hatano, H. Suemori, N. Nakatsuji, T. Tada, Octamer and Sox elements are required for transcriptional cis regulation of Nanog gene expression, Mol Cell Biol 25 (2005) 2475-2485. 


\section{Figure legends}

Figure 1 Detection of Nanog in human GI cancer tissues.

A. Analysis of SP cells in SW480 cells. SW480 cells were stained with Hoechst 33342 and analyzed by flow cytometry. SP cells were detected and outlined and shown as a percentage of total cells. SP cells were absent in the presence of verapamil.

B. Heat map of the expression levels of genes in SP and non-SP cells. The heat map maps expression values to a color gradient from low (blue) to high expression (red).

C. RT-PCR analysis in SP, non-SP and SW480 cells. For validation of each population, MDR I was tested. Nanog primer amplified 426 bp products, both Nanog and NanogP8 (forward, 5'-CAAAGGCAAACAACCCACTT-3'; and reverse, 5'-CTGGATGTTCTGGGTCTGGT-3').

Figure 2 Nanog expression in GI cancer tissues.

A. Detection of Nanog in human GI cancer cell lines by RT-PCR analysis. Total RNA (1 $\mu \mathrm{g})$ was isolated from gastric cancer cells (AZ521, MKN1), colon cancer cells (SW480, DLD1), breast cancer cells (MCF7), NEC8 cells (positive control for Nanog), and NIH3T3 cells (negative control for Nanog). PCR cycle number and annealing temperature for $N a n o g$ is 38 cycles and $58^{\circ} \mathrm{C}$, and for $\beta$-actin 18 cycles and $58^{\circ} \mathrm{C}$. Our primer design for Nanog amplifies the protein coding region in both Nanog and NanogP8. 
B. Western blot analysis. Nuclear protein $(40 \mu \mathrm{g})$ extracted from SW480, AZ521, and NEC8 cells was loaded in each lane. Am antibody for nucleoporin was used as loading control of nuclear protein.

C. Detection of Nanog in human GI cancer cells by RT-PCR analysis. Total RNA (1 $\mu \mathrm{g})$ was isolated from the cells of ascites and pleural effusion in GI cancer patients. PBMC from a healthy subject were used as a negative control for Nanog. Sample numbers $\# 8, \# 12, \# 18$ are ascites of colon cancer; $\# 1, \# 2, \# 4, \# 13, \# 17$ are pleural effusion of gastric cancers; \#3, \#5-7, \#9-11, \#14-16 are ascites of gastric cancers. PCR cycle number and annealing temperature for Nanog is 38 cycles and $58^{\circ} \mathrm{C}$, and for $\beta$-actin 18 cycles and $58^{\circ} \mathrm{C}$.

D. Western blot analysis. Nuclear protein $(10$ to $50 \mu \mathrm{g})$ extracted from clinical samples was loaded in each lane.

Figure 3 NanogP8 expression in GI cancer cells.

A. The differences in sequence between human Nanog and NanogP8 within the protein coding regions (918 bp). First line: human Nanog; second line: NanogP8. The translational start site is defined as +1 . There are only two changes from Nanog to NanogP8 in the inferred amino acid sequence: from K (AAG246) to N (AAT246) and from Q (CAG759) to H (CAC759), respectively.

The third line is the sequence of the Nanog protein coding region in human gastric cancer cells, AZ521, and the fourth line the Nanog protein coding region in cancer 
cells of sample (CS) \#10. Amino acid 629 changes from $\mathrm{C}$ to $\mathrm{T}$.

B. The sequencing results of RT-PCR product clones for the Nanog protein coding region, using a primer pair. Nanog: clone number of Nanog sequence alignment, NanogP8: NanogP8, Nanog variant: human Nanog splicing variant forms, and Unrecognized: unrecognized sequences with no homology to sequences in the GenBank database.

Figure 4 AZ521 cells and SW480 cells with human NanogP8.

A. Western blot analysis. Nuclear protein $(40 \mu \mathrm{g})$ extracted from two AZ521/mock and two AZ521/NanogP8 clones (a), two SW480/mock and two SW480/NanogP8 clones (b) were loaded in each lane.

B. ICC staining for NanogP8. (i)(ii) AZ521/NanogP8 cells. (i) cells with anti-Nanog antibodies and Texas-red-conjugated secondary antibodies. (ii) cells with DAPI.

Figure 5 Proliferation assay of NanogP8-overexpressing cells.

A. Proliferation assay of NanogP8-overexpressing cells.

WST-1 assay for AZ521/NanogP8 and AZ521/mock cells (a), and for SW480/NanogP8 and SW480/mock cells (b). Almost all cells had efficiently adhered after 12 or $18 \mathrm{~h}$, so the value at 12 or $18 \mathrm{~h}$ after seeding was used to normalize each value. The figure represents an average of at least three independent experiments with SD bars.

B. Cell cycle assay of NanogP8-overexpressing cells. 
(a) SW480/mock cells, and (b) SW480/NanogP8 cells at $72 \mathrm{~h}$.

S phase cells; $31.4 \%$ (a) and $42.2 \%$ (b).

C. Proliferation assay of NanogP8 knockdown cells.

Survival at $48 \mathrm{~h}$ shows that knockdown of NanogP8 by siRNA caused concentration-dependent suppression of AZ521 cell proliferation. Absorbance ratio comparative to control cells (without siRNA treatment) was calculated based on the WST-1 assay value at each siRNA concentration.

Figure 6 Proliferation of NanogP8 transfectants in immunodeficient mice.

AZ521/NanogP8 cells and AZ521/mock cells were subcutaneously injected in Rag2 $\gamma \mathrm{C}$ knockout mice. The tumor size after injection was measured daily.

Figure 7 NanogP8 expression in GI cancer tissues.

A, D, F: H\&E staining. B,C,E,G: IHC staining for NanogP8. H: IHC staining for Ki67

A. Gastric cancer of moderately to poorly differentiated adenocarcinoma.

B. NanogP8 expression in the infiltrative part of gastric cancer.

C. NanogP8 not expressed in the surface part.

D. Well-differentiated gastric adenocarcinoma.

E. NanogP8 expression in infiltrative part. 
F. Colon cancer of moderately differentiated adenocarcinoma.

G. NanogP8 expression in the infiltrative part of colon cancer.

H. Ki67 expression in the infiltrative part of colon cancer. 


\section{Figure.1}
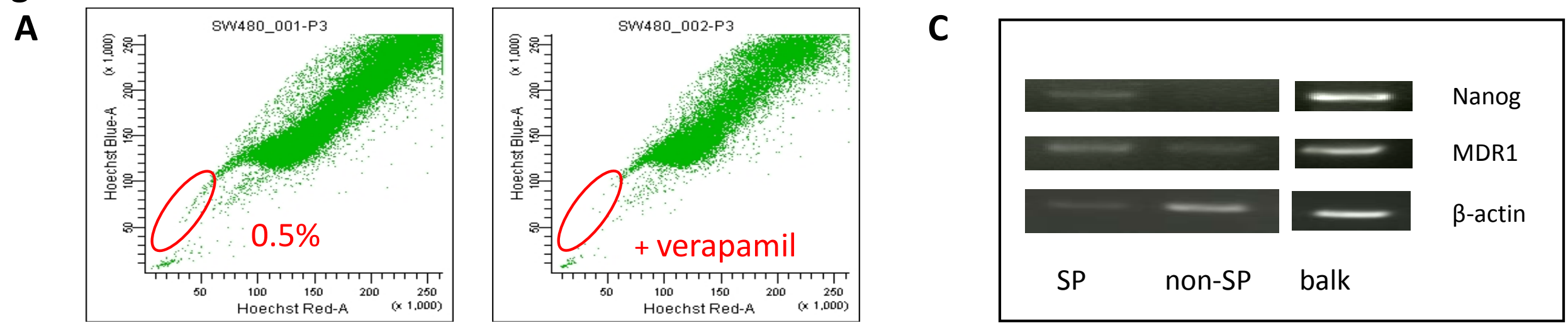

\section{B}
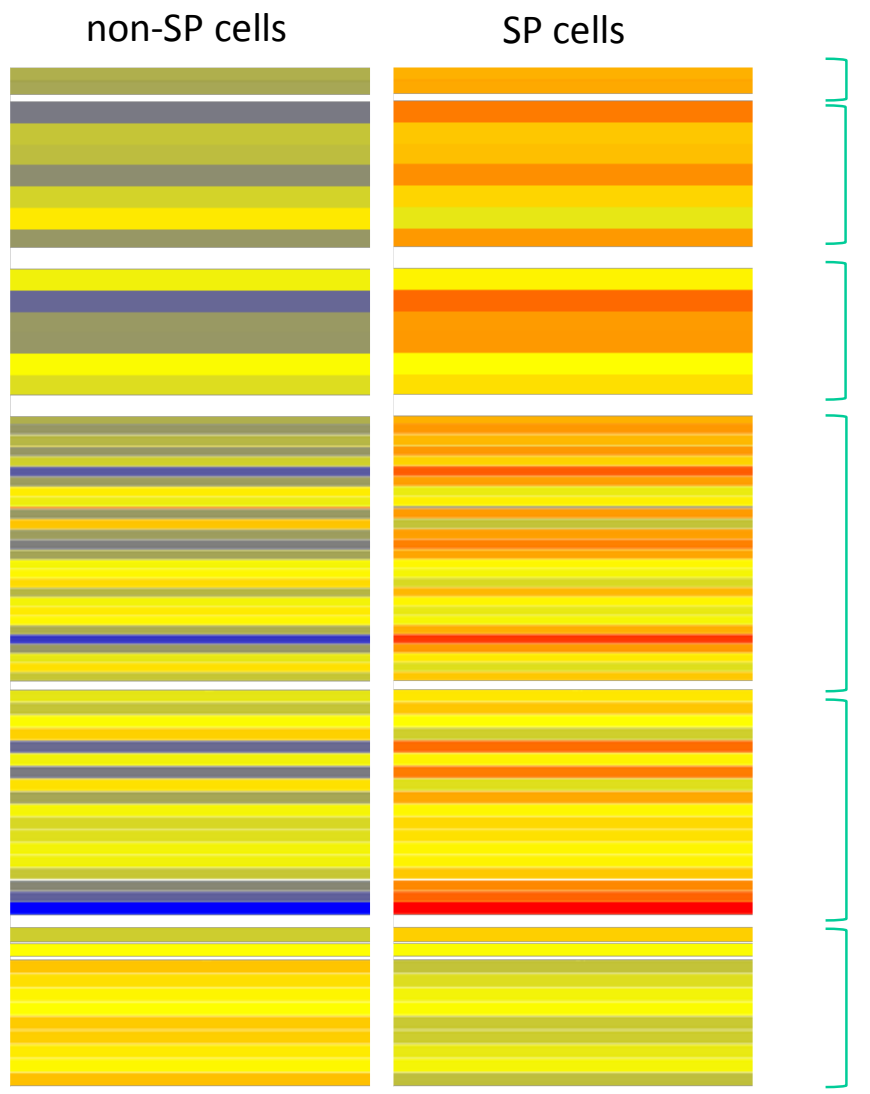

$A B C$ transporter genes

ES cell transcription factors

Several genes that encode developmentally

related homeodomain proteins

Wnt signal related genes

Notch signal related genes

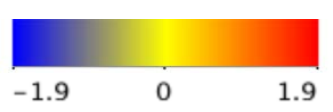




\section{Figure.2}

A

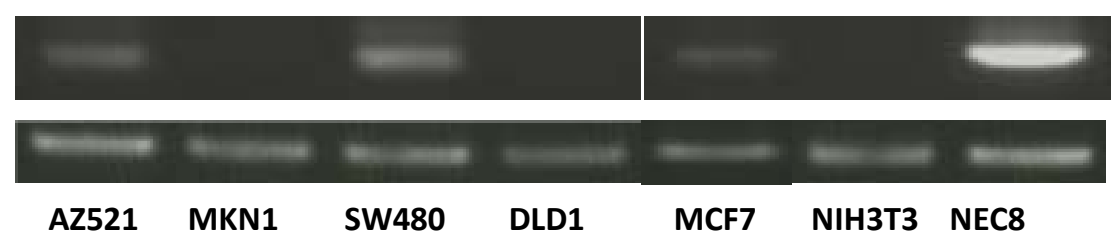

SW480 DLD1 MCF7 NIH3T3 NEC8

C
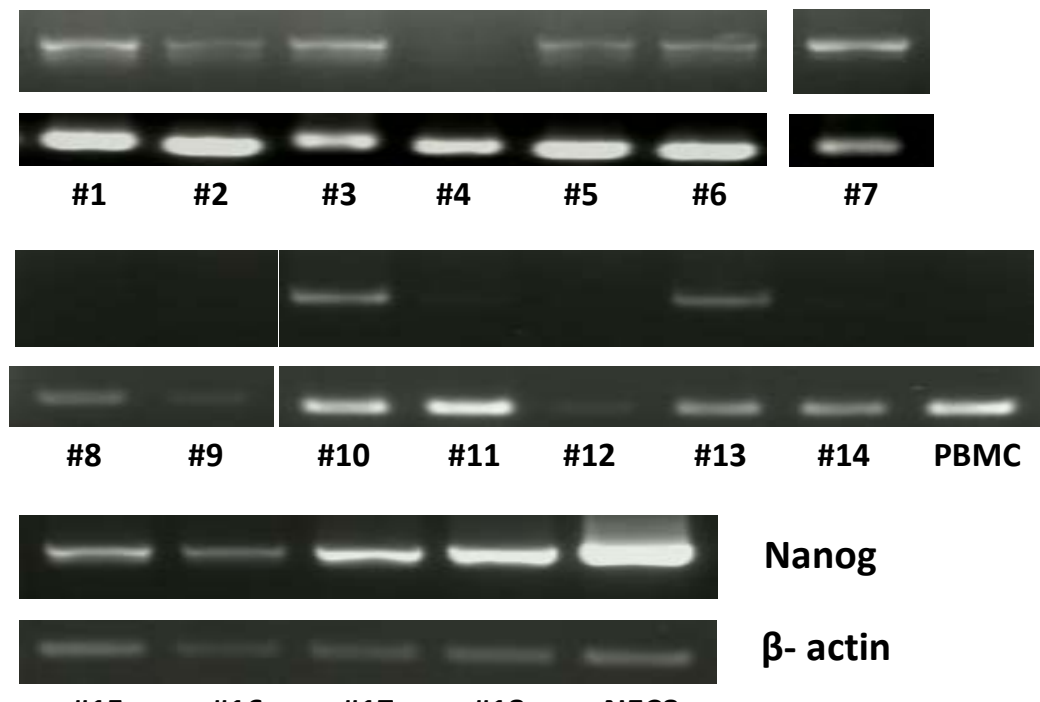

Nanog

$\beta$ - actin

Nanog

$\beta$ - actin

B

$37=$
(kDa)

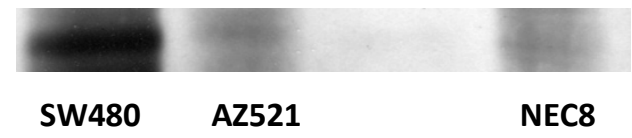

Nucleoporin

NEC8

D

Nanog

$\beta$ - actin

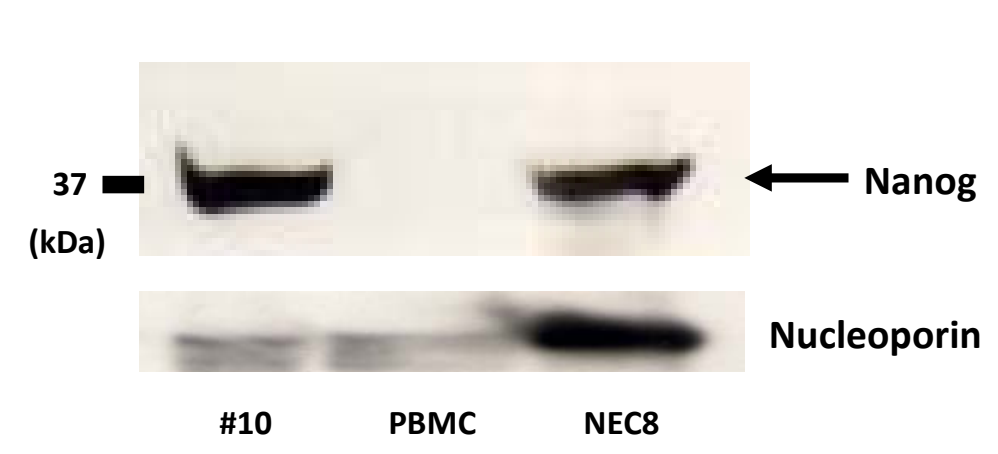




\section{Figure. 3}

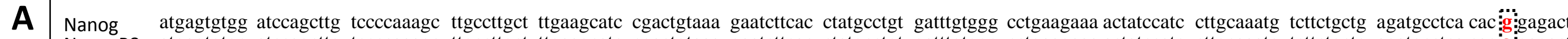
NanogP8 atgagtgtgg atccagcttg tccccaaagc ttgccttgct ttgaagcatc cgactgtaaa gaatcttcac ctatgcctgt gatttgtggg cctgaagaaa actatccatc cttgcaaatg tcttctgctg agatgcctca cac:a:gagact AZ521 atgagtgtgg atccagcttg tccccaaagc ttgccttgct ttgaagcatc cgactgtaaa gaatcttcac ctatgcctgt gatttgtggg cctgaagaaa actatccatc cttgcaaatg tcttctgctg agatgcctca cac:a:gagact CS \#10 atgagtgtgg atccagcttg tccccaaagc ttgccttgct ttgaagcatc cgactgtaaa gaatcttcac ctatgcctgt gatttgtggg cctgaagaaa actatccatc cttgcaaatg tcttctgctg agatgcctca cac:a :

gtctctcctc ttccttcctc catggatctg cttattcagg acagccctga ttcttccacc agtcccaaag gcaaacaacc cacttctgca gagaa gagtg tcgcaaaaa ggaagacaag gtcccggtca agaaacagaa gaccagaact gtgttctctt gtctctcctc ttccttcctc catggatctg cttattcagg acagccctga ttcttccacc agtcccaaag gcaaacaacc cacttctgca gagaa: gtctctcctc ttccttcctc catggatctg cttattcagg acagccctga ttcttccacc agtcccaaag gcaaacaacc cacttctgca gagaa!t agtg tcgcaaaaaa ggaagacaag gtcccggtca agaaacagaa gaccagaact gtgttctctt gtctctcctc ttccttcctc catggatctg cttattcagg acagccctga ttcttccacc agtcccaaag gcaaacaacc cacttctgca gagaa; t agtg tcgcaaaaaa ggaagacaag gtcceggtca agaaacagaa gaccagaact gcgttctctt

ccacccagct gtgtgtactc aatgatagat ttcagagaca gaaatacctc agcctccagc agatgcaaga actctccaac atcctgaacc tcagctacaa acaggtgaag acctggttcc agaaccagag aatgaaatct aagaggtggc ccacccagct gtgtgtactc aatgatagat ttcagagaca gaaatacctc agcctccagc agatgcaaga actctccaac atcctgaacc tcagctacaa acaggtgaag acctggttcc agaaccagag aatgaaatct aagaggtggc ccacccagct gtgtgtactc aatgatagat ttcagagaca gaaatacctc agcctccagc agatgcaaga actctccaac atcctgaacc tcagctacaa acaggtgaag acctggttcc agaaccagag aatgaaatct aagaggtggc ccacccagct gtgtgtactc aatgatagat ttcagagaca gaaatacctc agcctccagc agatgcaaga actctccaac atcctgaacc tcagctacaa acaggtgaag acctggttcc agaaccagag aatgaaatct aagaggtggc

agaaaaacaa ctggccgaag aatagcaatg gtgtgacgca gaaggcctca gcacctacct accccagcct :tactcttcc taccaccagg gatgcctggt gaaccegact gggaaccttc caatgtggag caaccagacc tggaacaatt agaaaaacaa ctggccgaag aatagcaatg gtgtgacgca gaaggcctca gcacctacct accccagcct agaaaaacaa ctggccgaag aatagcaatg gtgtgacgca gaaggcctca gcacctacct accccagcct : agaaaaacaa ctggccgaag aatagcaatg gtgtgacgca gaaggcctca gcacctacct accccagcct c: tactcttcc taccaccagg gatgcctggt gaacccgact gggaaccttc caatgtggag caaccagacc tggaacaatt

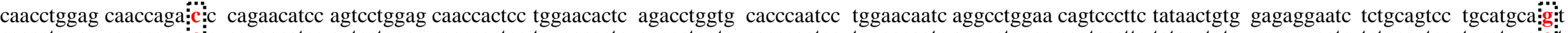
caacctggag caaccaga:c: cagaacatcc agtcctggag caaccactcc tggaacactc agacctggtg cacccaatcc tggaacaatc aggcctggaa cagtccttc tataactgtg gagaggaatc tctgcagtcc tgcatgca: : caacctggag caaccaga: caacctggag caaccagat c cagaacatcc agtcctggag caaccactcc tggaacactc agacctggtg cacccaatcc tggaacaatc aggcctggaa cagtcccttc tataactgtg gagaggaatc tctgcagtcc tgcatgcą cit

tccagccaaa ttctcctgcc agtgacttgg aggctgcctt ggaagctgct ggggaaggcc ttaatgtaat acagcagacc actaggtatt ttagtactcc acaaaccatg gatttattcc taaactactc catgaacatg caacctgaag acgtgtga tccagccaaa ttctcctgcc agtgacttgg aggctgcctt ggaagctgct ggggaaggcc ttaatgtaat acagcagacc actaggtatt ttagtactcc acaaaccatg gatttattcc taaactactc catgaacatg caacctgaag acgtgtga tccagccaaa ttctcctgcc agtgacttgg aggctgcctt ggaagctgct ggggaaggcc ttaatgtaat acagcagacc actaggtatt ttagtactcc acaaaccatg gatttattcc taaactactc catgaacatg caacctgaag acgtgtga tccagccaaa ttctcctgcc agtgacttgg aggctgcctt ggaagctgct ggggaaggcc ttaatgtaat acagcagacc actaggtatt ttagtactcc acaaaccatg gatttattcc taaactactc catgaacatg caacctgaag acgtgtga

B

\begin{tabular}{|c|c|c|c|c|}
\hline Sample & Nanog & NanogP8 & Nanog variant & Total clones \\
\hline Clinical Sample \#1 & - & $1 / 3$ & - & 3 \\
\hline Clinical Sample \#10 & - & $7 / 7$ & - & 7 \\
\hline Clinical Sample \#13 & - & $4 / 5$ & - & 5 \\
\hline Clinical Sample \#15 & - & $1 / 1$ & - & 1 \\
\hline Clinical Sample \#16 & - & $2 / 2$ & - & 2 \\
\hline Clinical Sample \#17 & - & $1 / 1$ & - & 1 \\
\hline Clinical Sample \#18 & - & $3 / 3$ & - & 3 \\
\hline
\end{tabular}


Figure.4

A

(a)

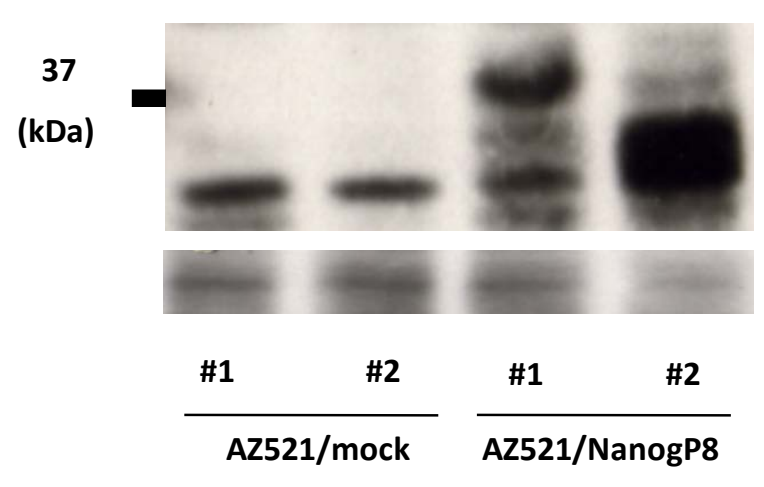

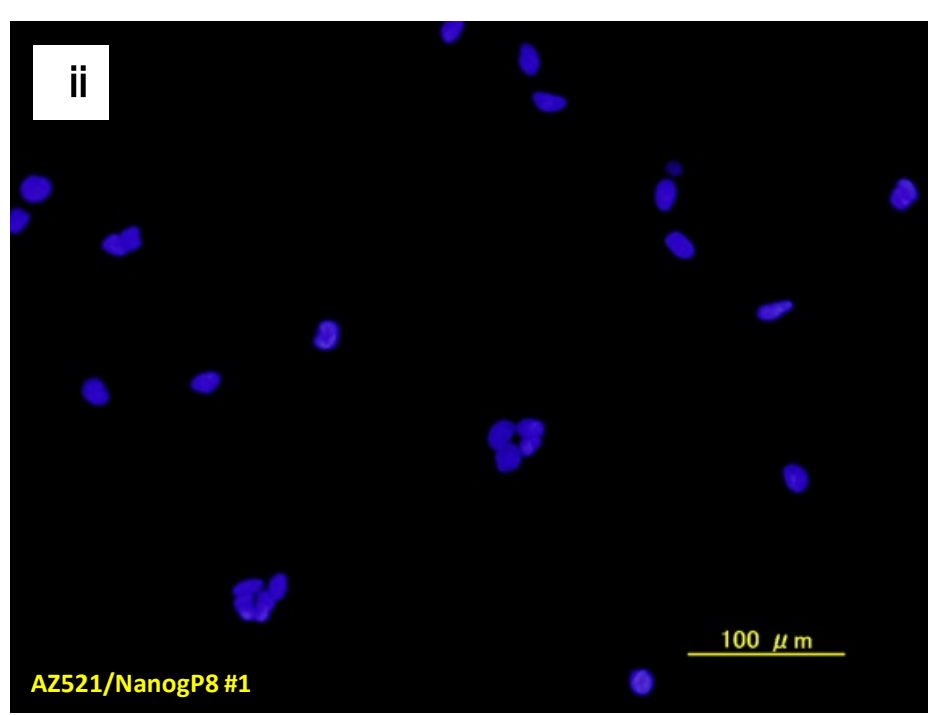

(b)

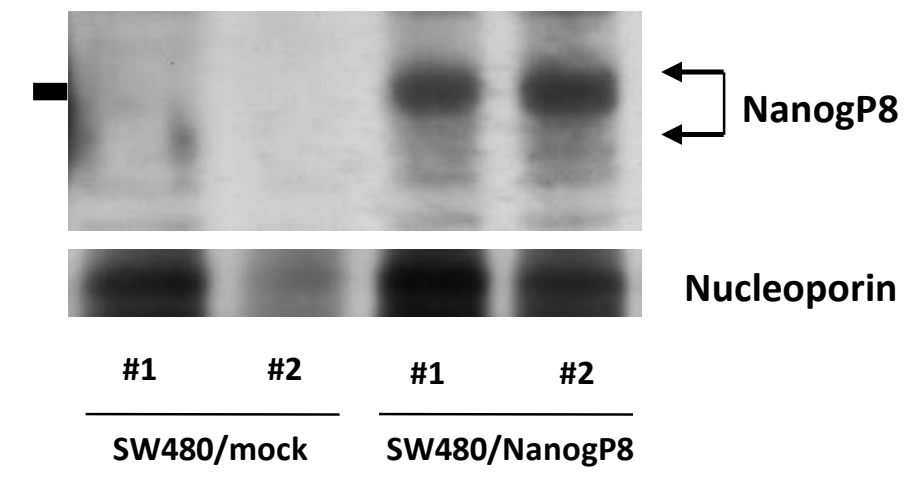

B

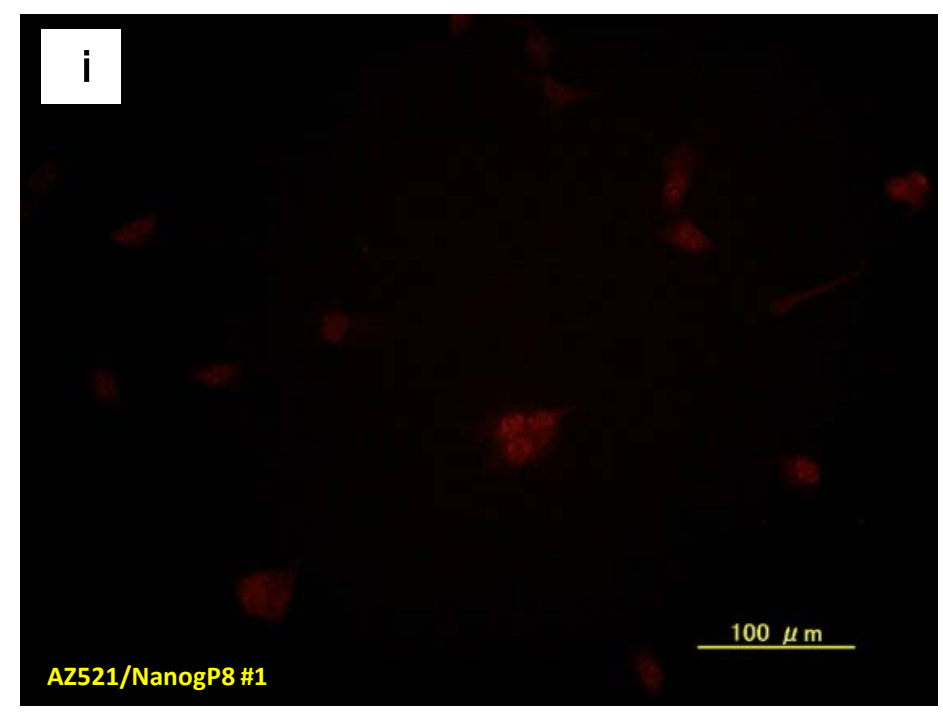




\section{Figure.5}

A

(a)

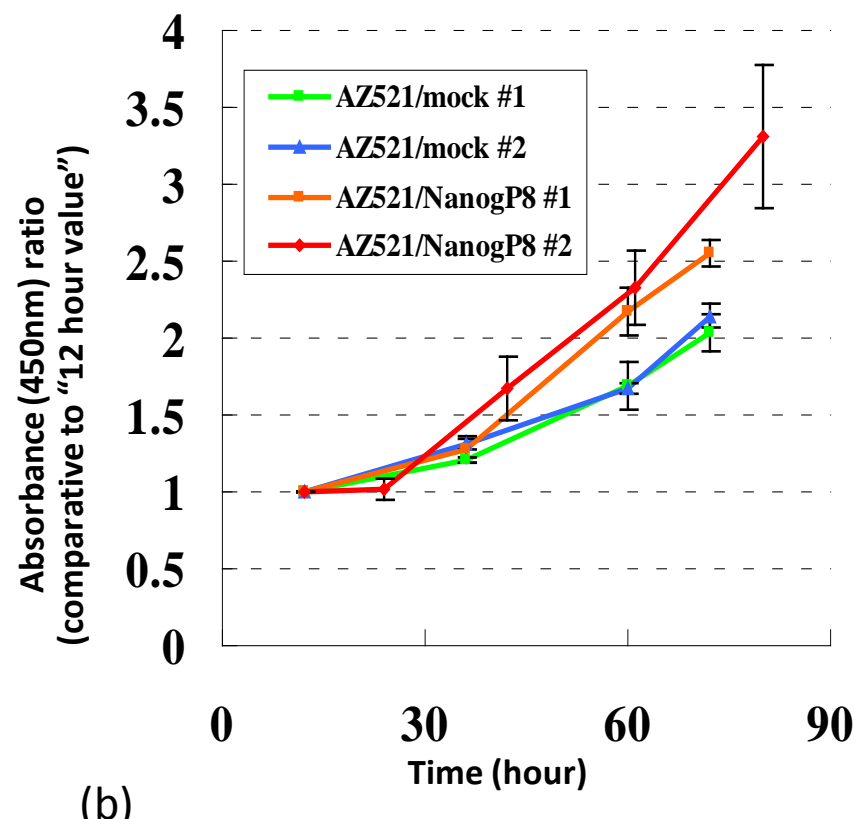

(b)

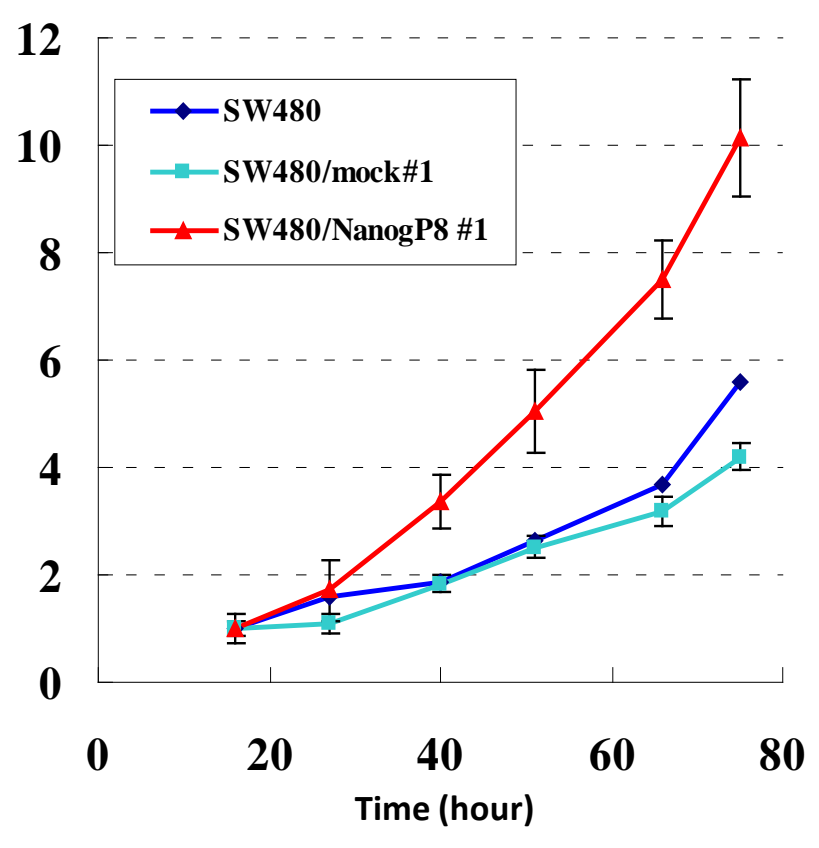

B (a)

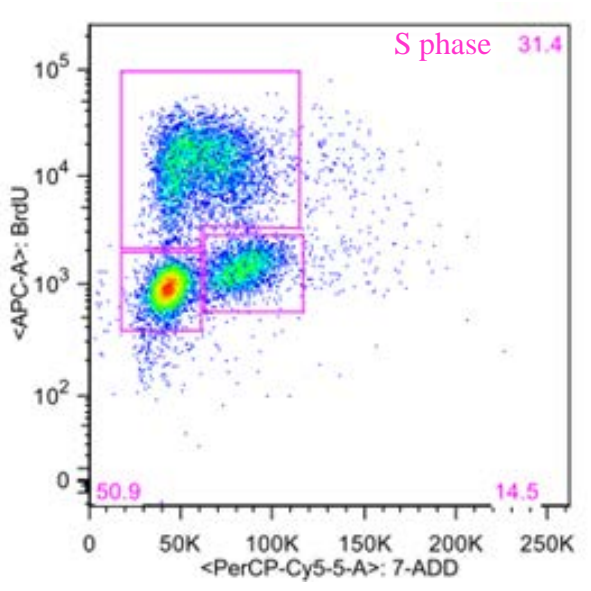

(b)

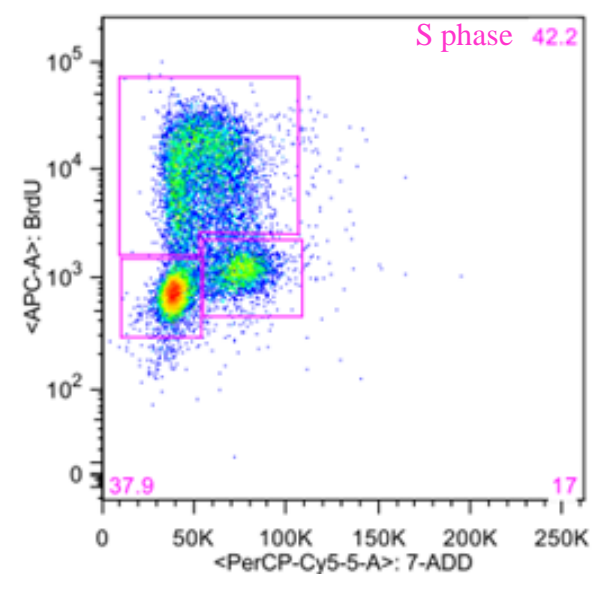

C

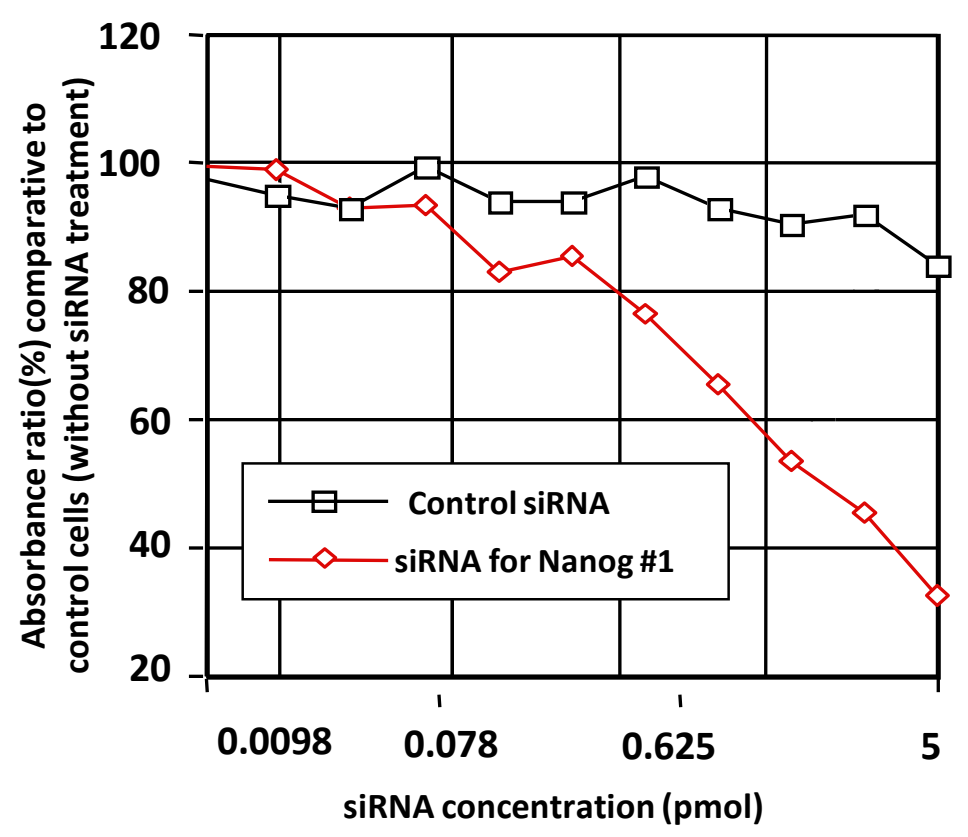




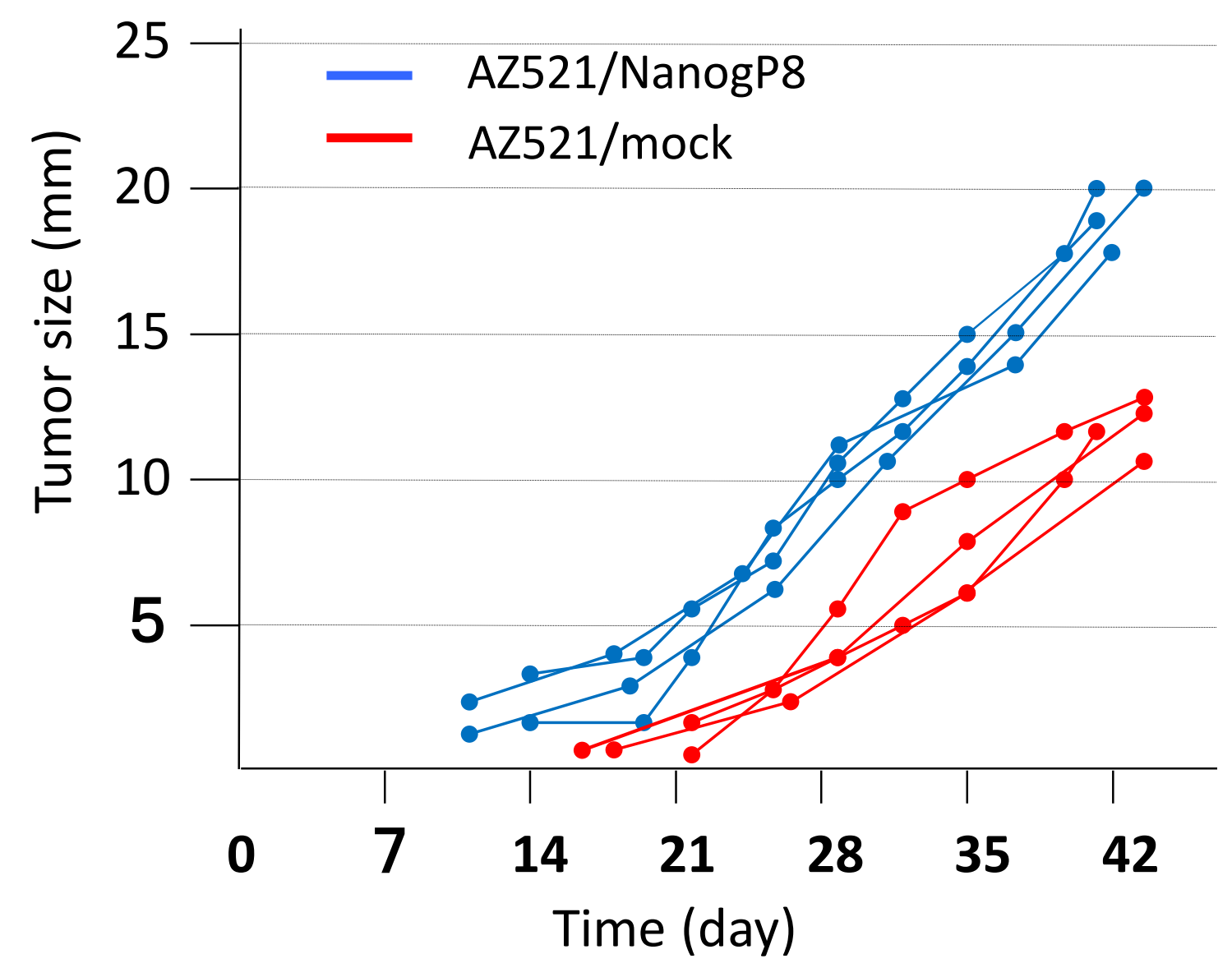


Figure.7
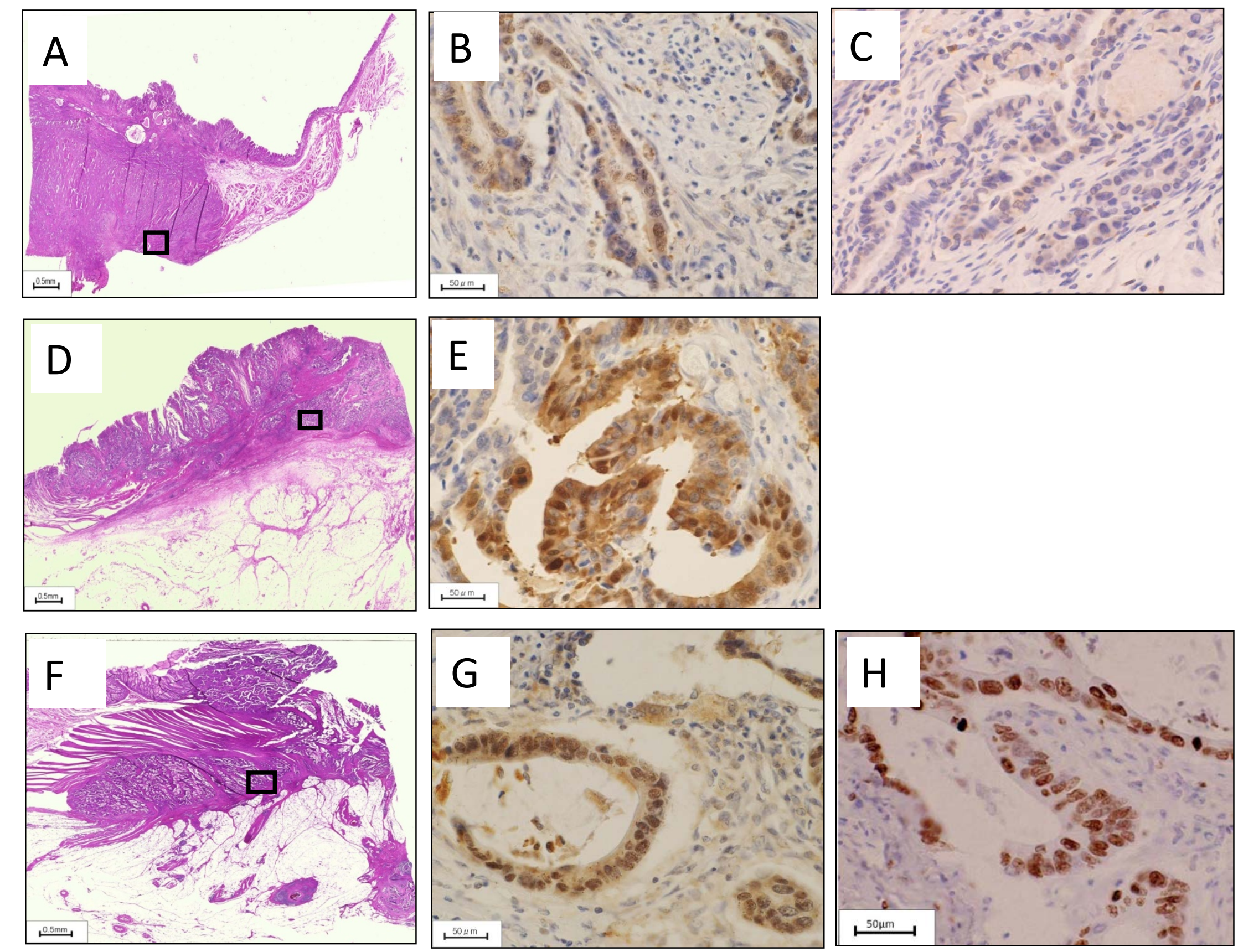